\title{
Technical Note: Root-plowing effects on nutritional value of browse and mast in south Texas
}

\author{
DONALD C. RUTHVEN III AND ERIC C. HELLGREN
}

\author{
Authors are graduate research assistant and associate professor, Caesar Kleberg Wildife Research Institute, Campus \\ Box 218, Texas A\&M University-Kingsville, 78363.
}

\begin{abstract}
Leaf and mast material was collected from mesquite (Prosopis glandulosa Torr.), huisache (Acacia smallii Isely), granjeno (Celtis pallida Torr.), and hog plum (Colubrina texana (T.\& G.) Gray) on both root-plowed and untreated sites in south Texas. Forages were analyzed for nitrogen (N), neutral detergent fiber (NDF), and in vitro dry matter digestibility (IVDMD). Forages differed among species for $\mathbf{N}, \mathrm{NDF}$, and IVDMD. Leaf IVDMD of huisache and hog plum was higher on untreated sites. Huisache mast was higher in N and NDF concentrations, but not IVDMD, on untreated sites. Browsers on root-plowed sites may be forced to use forages of fewer digestible nutrients than on untreated sites. The cause of changes in browse quality following brush manipulation should be examined.
\end{abstract}

Key Words: Acacia smallii, Celtis pallida, Colubrina texensis, digestibility, fiber, Prosopis glandulosa, nitrogen, white-tailed deer.

Root plowing is a common brush management method used to remove woody species that have invaded south Texas rangelands over the last 100-200 years. Following brush management, brush densities can rebound to levels similar to untreated brush sites in 20-25 years in the eastern Rio Grande Plains (Ruthven et al. 1993); however, reductions in brush diversity following root plowing remain (Fulbright and Beasom 1987, Ruthven et al. 1993). Effects of decreased woody plant diversity and increased herbaceous cover (Ruthven et al. 1993) on nutrient content and digestibility of major browse species found on root-plowed sites are unknown. Short-term effects of shredding (Everitt 1983) and roller-chopping (Reynolds et al. 1992) on nutritional quality of browses have been variable. Browse is an important dietary constituent for wildlife species, especially during summer and fall (Arnold and Drawe 1979, Ruthven et al. 1994). Therefore, it is important that the effects listed above be determined, so that land managers can better estimate effects of changes in browse com-

The authors thank King Ranch inc., especially R. H. Thompson, for access and permission to conduct the study. Financial support was provided by the Cacsar Kleberg Foundation for Wildlife Conservation.

Manuscript accepted 4 Feb. 1995. position on nutritional status of herbivores. Our objective was to compare percent total nitrogen $(\mathrm{N})$, neutral detergent fiber (NDF), and in vitro dry matter digestibility (IVDMD) of 4 dominant browse species (mesquite [Prosopis glandulosa Torr.], huisache [Acacia smallii Isely], granjeno [Celtis pallida Torr.], and hog plum [Colubrina texana T.\& G.] Gray) on untreated and root-plowed (treated) sites.

\section{Materials and Methods}

The study was conducted on the King Ranch, Santa Gertrudis Division, which covers 85,202 ha in western Kleberg and southeastern Jim Wells counties, within the eastern Rio Grande Plains of south Texas. Four study sites, 2 root plowed and 2 untreated, were chosen to evaluate effects of root plowing on key whitetailed deer (Odocoileus virginianus) forages. Treated areas were root plowed in 1973-1974 (Personal communication, R. H. Thompson). Treated pastures included the Lower Little (1,282 $\mathrm{ha}$ ) and Upper Little ( $870 \mathrm{ha})$, and untreated pastures included the Patricio (1,140 ha) and La Planta (679 ha). All study sites were within a circle of radius $5.8 \mathrm{~km}$ (Ruthven et al. 1993). Previous work indicated that woody species richness had been reduced, from 19 species on the untreated area to 7 species on the treated area (Ruthven et al. 1993). Of the herbaceous component, forb cover was greater on treated areas (Ruthven et al. 1994). Soils, vegetation, climate, and grazing history of this semi-arid, subtropical thorn forest were described by Ruthven et al. (1993).

Forage samples were collected during August and September 1991. Huisache mast was collected during early August. Mesquite mast and leaf material from mesquite, huisache, granjeno, and hog plum were collected during mid-September. Leaf material and mast were collected from 3 randomly selected groups of 5-6 associated trees or shrubs in each pasture for a total of 6 replicates/treatment (each motte of trees and shrubs was considered an independent site). Each site was sampled on only 1 day and all sampling was completed in $<4$ days. This scheme was chosen because during this period, seasonal browse use by deer was highest (Ruthven et al. 1994) and nutritive content of browse is lowest (Varner et al. 1977, Everitt and Gonzales 1981, Meyer et al. 1984). Because of the lack of mesquite mast, samples were taken from only 1 site in each treatment. Leaves and mast were hand-stripped from branches and twigs were discarded. Samples were air-dried at $40-45^{\circ} \mathrm{C}$ to a constant weight, then ground 
through a $1-\mathrm{mm}$ mesh screen in a Wiley Mill for laboratory analysis.

Nitrogen content of forages was determined by the microKjeldahl method (AOAC 1970). Neutral detergent fiber was estimated by methods described by Van Soest and Wine (1967). In vitro dry matter digestibility was determined by the methods of Moore and Mott $(1974,1976)$, using rumen fluid from an adult male white-tailed deer that was fed alfalfa hay and commercial deer pellets for 1 week before rumen fluid collection. Concentrated rumen fluid was collected by placing a tube into the rumen via the esophagus and massaging the rumen. Filtered, concentrated rumen fluid $(550 \mathrm{ml})$ was diluted to $750 \mathrm{ml}$ with distilled water for addition to a McDougal saliva solution before inoculation.

Leaf data were analyzed by 2-way analysis of variance (SAS 1987), with treatment and species as the main effects. Tukey's studentized range test was used to separate $(P<0.05)$ differences for multiple comparison among species. Mast was analyzed by a 1 -way analysis of variance with treatment as the main effect.

\section{Results}

Leaf material from untreated sites had higher digestibility (IVDMD) than that from root-plowed sites $(P<0.001)$. A speciestreatment interaction $(\mathrm{P}=0.013)$ indicated that treatment differences were greatest for huisache and hog plum (Table 1). Neutral detergent fiber and $\mathrm{N}$ content did not vary by treatment).

Species effects were noted for $N$, fiber (NDF), and digestibility (IVDMD) $(P<0.0001)$. Granjeno had higher $N$ content and IVDMD than the other 3 species. Huisache was also higher in $\mathrm{N}$ than mesquite, and hog plum had higher IVDMD than huisache. Mesquite and huisache had higher NDF values than granjeno and hog plum, and hog plum was also higher in NDF than granjeno.

Huisache mast had greater $\mathrm{N}(\mathrm{P}=0.003)$ and fiber $(\mathrm{NDF})(\mathrm{P}=$ 0.002 ) concentrations on untreated than on treated sites. Total $N$ was $17 \%$ greater $(2.96+0.09$ vs $2.47+0.09 \%)$ and NDF was $22 \%$ greater $(29.6+1.0$ vs $23.1+1.0 \%)$ on untreated areas than on treated sites. Huisache mast digestibility (IVDMD) was simi$\operatorname{lar}(P>0.05)$ between treatments $(77.0+1.0$ untreated vs $79.6+$ $2.0 \%$ treated). Mesquite mast had similar N ( = 1.74\%), NDF ( = $34.9 \%$ ), and IVDMD $(=70.7 \%)$ on untreated and treated sites.

Table 1. Percent nitrogen (N), neutral detergent fiber (NDF), and in vitro dry matter digestibility (IVDMD) of leaves of huisache, mesquite, granjeno, and hog plum for untreated (U) and root-plowed (RP) sites at the Santa Gertrudis Division of the King Ranch, Kleberg and Jim Wells Counties, Texas, 1991.

\begin{tabular}{|c|c|c|c|c|c|c|c|}
\hline \multirow[b]{2}{*}{ Species } & \multicolumn{2}{|l|}{$N$} & \multicolumn{2}{|c|}{$\mathrm{NDF}$} & \multicolumn{3}{|c|}{ IVDMD } \\
\hline & $\begin{array}{r}\text { Mean } \\
U \& \text { \&P }\end{array}$ & SE & $\begin{array}{c}\text { Mean } \\
\text { U\& RP }\end{array}$ & SE & $\mathrm{U}$ & $\mathbf{R P}$ & SE \\
\hline Huisache & $4.28 b^{1}$ & 0.11 & $37.4 \mathrm{a}$ & 0.6 & $67.2 \mathrm{c}$ & $59.3 \mathrm{~d}$ & 1.6 \\
\hline Mesquite & $3.82 \mathrm{c}$ & 0.08 & $38.2 a$ & 0.6 & $66.1 \mathrm{c}$ & $64.6 \mathrm{c}$ & 0.7 \\
\hline Granjeno & $5.00 \mathrm{a}$ & 0.09 & $26.7 \mathrm{c}$ & 0.3 & 89.1 a & $88.0 \mathrm{a}$ & 0.6 \\
\hline Hog Plum & $3.96 b c$ & 0.08 & $29.0 \mathrm{~b}$ & 0.4 & $71.8 \mathrm{~b}$ & $63.8 \mathrm{c}$ & 1.7 \\
\hline
\end{tabular}

${ }^{1}$ Means in a column followed by the same letrer are similar $(P>0.05)$. Mean separation by species is by Tukey's studentized range test.

\section{Discussion}

Our estimates of $\mathrm{N}$ conccntration and digestibility (IVDMD) were consistently higher than those previously recorded (Everitt and Gonzales 1981; Meyer et al. 1984, Varner and Blankenship 1987). Several factors could be responsible for the higher concentration relative to those previously reported. First, all study sites received an average of approximately $9.8 \mathrm{~cm}$ of precipitation during a 45-day period before sample collection (Unpublished data, P. S. Lieck). All forages, especially hog plum, showed lush, spring-like regrowth and resprouting. Varner and Blankenship (1987) reported April concentrations of $5 \% \mathrm{~N}$ for granjeno and May concentrations of $3.9 \% \mathrm{~N}$ for hog plum, which were similar to our September values. Second, our samples contained only leaf material, whereas earlier researchers included twigs (Varner et al. 1977, Everitt and Gonzales 1981), which are lower in N concentration and digestibility than leaves. Third, samples were inoculated with rumen fluid collected from a live animal within 30-60 minutes. Samples of Everitt and Gonzales (1981) and Varner et al. (1977) were not inoculated until 1-2 hours after collection, which may have resulted in increased microbial mortality leading to lower digestion.

Treatment differences in leaf digestibility (IVDMD) were not consistent across species, although IVDMD of leaf material of all 4 major woody species from root-plowed sites was lower than from untreated areas. These data suggest that browsers on rootplowed sites would be forced to utilize browse of fewer digestible nutrients during periods when browse is a major constituent of their diet. However, greater dietary reliance on more abundant forbs on root-plowed sites (Ruthven et al. 1994), lack of treatment effects for IVDMD of huisache mast (which comprised as much as $50 \%$ of white-tailed deer diets during the fall on rootplowed sites) (Ruthven et al. 1994), diet selection by deer, or statistical differences that were not of biological significance may reduce the impacts of differences of browse quality.

Future research is warranted to examine differences in nutrient quality in browse following brush management. Questions to be asked include, can the differences that we observed be replicated? Also, what causes differences in browse quality following brush manipulation? Lastly, if differences occur, are they of a magnitude large enough to affect reproduction or survival of browsing herbivores?

\section{Literature Cited}

Arnold, L. A., and D. L. Drawe. 1979. Seasonal food habits of whitetailed deer on the South Texas Plains. J. Range Manage. 32:175-178.

AOAC. 1970. Official methods of analysis. 11th ed. Assoc. Off. Anal. Chem., Washington, D. C. 1015 pp.

Everitt, J. H. 1983. Effects of plant shredding on nutrient content of four south Texas deer browse species. J. Range Manage. 36:779-781.

Everitt, J. H, and G. L. Gonzales. 1981. Seasonal nutrient content in food plants of white-tailed deer on the south Texas plains. J. Range Manage. 34:506-510.

Fulbright, T. E., and S. L. Beasom. 1987. Long-term effects of mechanical treatments on white-tailed deer browse. Wildl. Soc. Bull. 15:560-564.

Meyer, M. W., R. D. Brown, and M. W. Graham. 1984. Protein and energy content of white-tailed deer diets in the Texas coastal bend. J. Wildl. Manage. 48:527-533. 
Moore, J. E., and G. O. Mott. 1974. Recovery of residual organic matter from in vitro digestion of forages. J. Dairy Sci. 57:1258-1259.

Moore, J. E., and G. O. Mott. 1976. Fermentation tubes for in vitro digestion of forages. J. Dairy Sci. 59:167-169.

Reynolds, J. P., T. E. Fulbright, and S. L. Beasom. 1992. Mechanical rejuvenation to dampen seasonal variation in chemical composition of browse. J. Range Manage. 45:589-592.

Ruthven, D. C. III., T. E. Fulbright, S. L. Beasom, and E. C. Hellgren. 1993. Long-term effects of root plowing on vegetation in the eastern south Texas plains. J. Range Manage. 46:351-354.

Ruthven, D. C. III., E. C. Hellgren, and S. L. Beasom. 1994. Effects of root plowing on white-tailed deer condition, population status, and diet. J. Wildl. Manage. 58:59-70.
SAS Institute Inc. 1987. SAS User's guide: Statistics, 1982 edition. SAS Institute Inc., Cary, N.C.

Van Soest, P. J., and R. H. Wine. 1967. Use of detergents in the analysis of fibrous feeds. IV. The determination of plant cell wall constituents. J. Assoc. Official Anal. Chem., 50:50.

Varner, L. W., and L. H. Blankenship. 1987. Southern Texas shrubs nutritive value and utilization by herbivores. pp. 108-112 In: Proceedings of symposium on plant - herbivore interactions (F. D Provenza, J. T. Flinders, and E. D. McArthur, eds.). USDA Forest Serv. Gen. Tech. Rep. INT-222.

Varner, L. W., L. H. Blankenship, and G. W. Lynch. 1977. Seasonal changes in nutritive value of deer food plants in south Texas. Proc. Ann. Conf. Southeastern Assoc. Fish Wildl. Agencies 31:99-106. 